\title{
Pelatihan Penggunaan Mmicrosoft Office Bagi Guru SMP Al-Hamidiyah Palembang
}

\author{
Masayu Rosyidah ${ }^{1}$, Marhaini ${ }^{2}$, Reny Kartika Sary ${ }^{3}$, Febi Ardianto ${ }^{4}$, Yosi Apriani ${ }^{5}$ \\ Universitas Muhammadiyah Palembang \\ Jalan Jenderal Ahmad Yani 13 Ulu Palembang 30253 \\ ,email : rosyidahmasayu@gmail.com
}

\begin{abstract}
ABSTRAK
Guru adalah pendidik profesional dengan tugas mendidik, mengajar, membimbing, mengarahkan, melatih, menilai, dan mengevaluasi peserta didik pada pendidikan anak usia dini maupun menengah pada Lembaga formal tertentu. Salah satu masalah yang dihadapi guru SMP Al-Hamidiyah adalah masih rendahnya kompetensi yang dimiliki guru terutama pada penggunaan perangkat teknologi komputer. Hal ini sangat disayangkan, padahal tuntutan pada tugas guru seiring telah berlakunya kurikulum 2013, dimana guru dituntut untuk bekerja dengan menggunakan aplikasi, media pembelajaran dengan menggunakan teknologi informasi, sistem penilaian berbasis aplikasi, ujian nasional berbasis komputer, dan lainnya. Kendala ini terjadi karena masih kurangnya motivasi guru untuk menambah kompetensi di luar tugas pokok dengan berbagai alasan yang disampaikan. Pendekatan yang digunakan dalam kegiatan pengabdian ini dengan pendekatan persuasif-edukatif, dengan memberikan pengetahuan, pemahaman, dan keterampilan dalam menggunakan Microsoft Office. Metode yang digunakan berupa ceramah, praktek, dan diskusi. Hasil dari pengabdian ini guru memahami dan mampu mempraktekkan langsung.
\end{abstract}

Keywords: guru, kompetensi, microsoft office, kurikulum

\begin{abstract}
The teacher is a professional educator with the task of educating, teaching, guiding, directing, training, assessing, and evaluating students in early and secondary education in certain formal institutions. One of the problems faced by Al-Hamidiyah Middle School teachers is the low competency of teachers, especially in the use of computer technology devices. This is unfortunate, even though the demands on teachers' assignments are in line with the enactment of the 2013 curriculum, where teachers are required to work using applications, learning media using information technology, application-based assessment systems, computer-based national exams, and others. This obstacle occurs because there is still a lack of teacher motivation to add competence outside the main task for a variety of reasons conveyed. The approach used in this dedication activity with a persuasive-educative approach, by providing knowledge, understanding, and skills in using Microsoft Office. The method used in the form of lectures, practice, and discussion. The results of this dedication the teacher understands and is able to practice directly.
\end{abstract}

Keywords : teacher, competence, Microsoft office, curriculum 


\section{PENDAHULUAN}

SMP Al-Hamidiyah Palembang berlokasi di jalan Masjid Kiai Muara Ogan Rt. 01 Kertapati Palembang. Dengan izin operasional pada tahun 1999. Dan sudah mengeluarkan beberapa orang alumni lebih dari 10 angkatan. Berdasarkan data Dapodikdasmen tahun 7 September 2019, SMP Al-Hamidiyah Palembang memiliki NPSN 10609485, status Swasta, bentuk pendidikan SMP, status kepemilikan Yayasan, SK Pendirian Sekolah 919/I.11/F/1999, tanggal SK Pendirian 12 April 1999, SK Izin Operasional 919/I.11/F/1999, dan tanggal SK Izin Operasional 12 April 1999. Saat ini sudah memberlakukan kurikulum 2013 untuk kelas VII dan Kelas VIII, sementara kelas IX masih memberlakukan KTSP. Jumlah siswa saat ini untuk kelas VII, VIII, dan IX sebanyak 256 orang siswa. Tenaga pengajar terdiri dari 13 orang dan merupakan tenaga honorer. Saat ini sudah memiliki 4 (emapat) orang guru bersertifikasi antara lain mata pelajaran Pendidikan Agama Islam, Ilmu Pengetahuan Alam, Bahasa Inggris, dan Ilmu Pengetahuan Sosial. Pada pelaksanaannya, SMP AlHamidiyah memiliki 1 (satu) orang operator.

Berdasarkan Undang-Undang Republik Indonesia Nomor 14 Tahun 2005 tentang Guru dan Dosen menjelaskan bahwa kompetensi guru adalah seperangkat pengetahuan, keterampilan, dan perilaku yang harus dimiliki, dihayati, dan dikuasai oleh guru atau dosen dalam melaksanakan tugas keprofesionalan. Kompetensi dapat dikatakan sebagai kemampuan yang harus dimiliki oleh guru dalam melaksanakan tugasnya yang menunjukkan profesionalitas seorang guru.

Dalam proses pembelajaran guru dituntut bukan hanya transfer ilmu kepada siswa akan tetapi juga guru harus mampu mengembangkan diri untuk menambah kompetensi diri supaya lebih aktif untuk berkreasi sesuai dengan perkembangan zaman dan kemajuan teknologi saat ini.

Permasalahan yang dihadapi di SMP Al-Hamidiyah adalah masih rendahnya kemampuan guru dalam penggunaan perangkat komputer sederhana dalam penggunaan Microsoft office (Word, Excel, dan power point). Tujuan dari pengabdian ini adalah memberikan pelatihan secara langsung atau praktek langsung kepada guru mengenai penggunaan perangkat komputer dan aplikasinya. Manfaat yang diharapkan adalah bahwa guru ke depannya lebih familiar dengan perangkat komputer, mampu menggunakan perangkat komputer, memahami penggunaan Microsoft office untuk menunjang pembelajaran dan penilaian akhir, dan keperluan lainnya terkait perannya sebagai guru.

Komputer merupakan perangkat yang sangat membantu dalam kehidupan. Ada banyak program yang ada di dalamnya yang membantu kita untuk dapat mengerjakan pekerjaan agar lebih cepat dan lebih tepat. Salah satu program yang sangat penting yang wajib dimiliki dan wajib dikuasai oleh seorang pengguna komputer adalah Microsoft Office. Sesuai dengan namanya, program ini dapat membantu anda untuk mengerjakan pekerjaan kantor dengan lebih mudah. Di dalam Microsoft Office ada banyak jenis program yang bisa digunakan, yaitu Microsoft Word, Microsoft Excel, Microsoft Access, Microsoft Power Point dan masih banyak yang lainnya. Microsoft Office adalah perangkat lunak paket aplikasi perkantoran buatan Microsoft dan dirancang untuk dijalankan di bawah sistem operasi Microsoft Windows dan Mac OS X. Beberapa aplikasi di dalam Microsoft Office yang terkenal adalah Excel, Word, dan PowerPoint. Versi terbaru dari Aplikasi Microsoft Office adalah Office 15 (Office 2013) yang diluncurkan 29 Januari 2013. 


\section{Microsoft Office Word}

Microsoft Word merupakan satu program yang sangat penting dalam kehidupan sehari-hari. Program ini tidak hanya dapat membantu pekerjaan kantor menjadi lebih mudah tapi juga dalam bidang lainnya seperti pekerjaan sekolah dan untuk kebutuhan-kebutuhan lainnya. Program ini merupakan program pengolahan kata sehingga bagi yang ingin membuat dokumen yang berhubungan dengan kata akan lebih maksimal jika dilakukan di sini. Hal ini disebabkan karena ada banyak fungsi yang dimiliki oleh Microsoft Word yang tidak dimiliki oleh bagian Microsoft Office yang lain. Program ini pertama kali dikenalkan pada tahun 1983, pada masa perkenalannya program ini merupakan program dikenal sebagai Multi Tool World dan digunakan untuk Xenix. Secara resmi, Microsoft Word digunakan dalam sistem operasi Windows pada Microsoft Office 2003 dan hingga saat ini terus berkembang. Dalam perjalanannya, Microsoft Word memiliki perubahan nama yaitu pada tahun 2013 berganti nama menjadi Word tapi hingga saat ini nama Microsoft Word terus melekat padanya. Sebagai aplikasi pengolahan kata, Microsoft Word memiliki banyak fungsi yang penting. Karena digunakan untuk membuat dokumen kata, maka fungsi dari Microsoft Word ini lebih menjurus pada pembuatan buku. Oleh karena itu ada banyak fungsi yang dimiliki oleh Microsoft Word ini yang memudahkan pekerjaan untuk mengolah sebuah buku.

\section{Microsoft Office Excel}

Program lain yang sangat penting untuk dikuasai dalam Microsoft Office adalah Microsoft Excel. Jika Microsoft Word merupakan Program yang dirancang untuk melakukan pengolahan kata, maka Microsoft Excel ini merupakan Program yang di desain untuk melakukan pengolahan angka. Program ini merupakan Program yang dibuat dan diaplikasikan di 2 sistem operasi yaitu pada Microsoft Windows dan juga Mac OS. Sesuai dengan tugasnya yaitu untuk melakukan pengolahan angka, maka Microsoft Excel dilengkapi dengan berbagai macam fungsi untuk kalkulasi. Dengan menggunakan Program ini, maka bisa melakukan perhitungan data dalam wujud angka dengan lebih mudah. Mulai dari menghitung, mengurang bahkan hitungan-hitungan yang sulit sekalipun. Selain itu masih banyak lagi fungsi yang dimiliki oleh Program Microsoft Excel ini. Banyaknya fungsi tersebut menyebabkan Program ini menjadi salah satu Program yang paling banyak digunakan dalam komputer user hingga saat ini.

Seperti yang disebutkan sebelumnya, Program Microsoft Excel ini memiliki sangat banyak fungsi yang bisa digunakan dalam pengolahan data berwujud angka. Selain banyak fungsi untuk melakukan penghitungan angka, Microsoft Excel dilengkapi dengan kelebihan lainnya yang membuat Program ini menjadi makin banyak digunakan. Seperti fungsi logika dan juga sedikit fungsi pengolahan kata.

Bedanya pengolahan kata pada Microsoft Word dengan pengolahan kata pada Microsoft Excel ini adalah ada pada penggunaannya. Jika Microsoft Word menggunakan kata untuk dibuat dokumen tapi Microsoft Excel melakukan pengolahan kata dalam rangka menghasilkan sebuah hasil.

Misalnya pencarian nilai berdasarkan kata tertentu semuanya bisa dilakukan dengan menggunakan Microsoft Excel ini. Karena memiliki banyak input dan memberikan banyak kemudahan dalam pengerjaan tugas, tidak jarang banyak orang yang malah menggunakan Program Microsoft Excel untuk membuat dokumen pengolahan kata. 


\section{Microsoft Office Power Point}

Microsoft PowerPoint atau Microsoft Office PowerPoint atau PowerPoint adalah sebuah program komputer untuk presentasi yang dikembangkan oleh Microsoft di dalam paket aplikasi kantoran mereka, Microsoft Office, selain Microsoft Word, Excel, Access dan beberapa program lainnya. PowerPoint berjalan di atas komputer PC berbasis sistem operasi Microsoft Windows dan juga Apple Macintosh yang menggunakan sistem operasi Apple Mac OS, meskipun pada awalnya aplikasi ini berjalan di atas sistem operasi Xenix. Aplikasi ini sangat banyak digunakan, apalagi oleh kalangan perkantoran dan pebisnis, para pendidik, siswa, dan trainer. Dimulai pada versi Microsoft Office System 2003, Microsoft mengganti nama dari sebelumnya Microsoft PowerPoint saja menjadi Microsoft Office PowerPoint. Lalu, pada Office 2013, namanya cukup disingkat PowerPoint. Versi terbaru dari PowerPoint adalah versi 15 (Microsoft Office PowerPoint 2013) yang tergabung ke dalam paket Microsoft Ofice 2013.

Ada fungsi pengolahan kata, fungsi pengolahan angka dan juga fungsi pengolahan keindahan. Program ini bisa menggunakan gambar, simbol, huruf, angka, bahkan juga grafik dengan banyak pilihan format untuk disesuaikan dengan format yang anda inginkan. Meski ada banyak fungsi pengolahan yang bisa dijalankan di Program Microsoft Power Point ini tapi fungsi pengolahannya tidak sedetail yang dimiliki oleh Program Microsoft yang lainnya. Dalam Microsoft Power Point ini lebih fokus pada keindahan slide yang ditampilkan.

Selain memiliki banyak fungsi seperti yang disebutkan sebelumnya, ada fungsi utama yang dimiliki oleh Program Microsoft Power Point ini. Fungsi tersebut adalah fungsi animasi. Program ini memiliki banyak jenis animasi yang bisa diberikan pada objek dalam slide baik itu objek kata maupun objek grafis. Selain itu ada juga fungsi transisi untuk perpindahan slide satu ke slide yang lainnya agar presentasi menjadi makin menarik. Sesungguhnya ada juga Program yang dapat membantu untuk membuat presentasi yang lebih menarik dibandingkan dengan Microsoft Power Point akan tetapi biasanya akan ada watermark atau fee yang diminta untuk membayar untuk menggunakan Program mereka.

\section{METODE}

Kegiatan Pengabdian Masyarakat ini diberikan kepada guru dan staf di SMP Al-Hamidiyah Palembang dalam bentuk pelatihan. Secara substansi kegiatan ini selain memberikan dasar-dasar pengetahuan cara pengerjaan dokumen dan presensi dengan menggunakan program Microsoft sehingga mencapai tujuan yang ditargetkan. Adapun metode yang dilakukan dalam pelaksanaan pengabdian masyarakat ini adalah:

a. Pengajaran

Metode yang digunakan untuk memberikan pengetahuan dan pemahaman mengenai cara pembuatan dokumen dan presentasi dengan metode pengajaran dan praktik langsung di kelas. Materi yang disampaikan dalam pengajaran dan praktik ini dimulai dengan memperkenalkan tentang segala yang terlihat di layar dan pada papan keyboard, hal ini untuk membuka wawasan mengenai interaksi dan responsi yang diperlukan antar kedua perangkat tersebut. Peserta diberikan gambaran umum tentang setiap fungsi tombol keyboard dan hasil yang bisa dilihat pada layar dengan menerapkan praktik sederhana. Kemudian peserta diberikan 
JAMALI - Volume. 01, Issue. 02, September 2019

pemahaman tentang sebuah contoh kasus dalam hal ini adalah bisa dari kegiatan rutin peserta, contohnya ada peserta yang kegiatan rutin yang dilakukan adalah membuat lembar tugas, pembuatan data siswa, penilaian, surat menyurat, dan materi pembelajaran.

b. Tutorial (Pendampingan)

Peserta diberikan pendampingan berupa operasi/trik langkah sederhana untuk mencapai rancangan aplikasi yang sedang dibuat, contohnya pembuatan margin, pengaturan warna latar belakang layar atau ukuran huruf/angka, pembuatan tabel, cara mencantumkan gambar atau teks, dan pembuatan animasi. Peserta diajak untuk memecahkan permasalahan yang sering timbul pada umumnya yang terjadi seputar pengoperasian tombol dan mengorganisir luaran yang diharapkan.

c. Diskusi

Peserta pelatihan diberikan kesempatan untuk mendiskusikan permasalahan yang berkaitan dengan penyelesaian aplikasi program yang sedang dibuat atau hal-hal yang berkenaan dengan topik yang sedang dikerjakan.

d. Tanya Jawab

Sebelum pelaksanaan pemberian materi, peserta diberikan quesioner dalam bentuk googleform sebagai pre test untuk melihat sejauh mana peserta memiliki pengetahuan terkait materi sebelum ceramah untuk mendapatkan pengetahuan sebelum kegiatan pengabdian dilakukan, serta hal yang sama juga dilakukan setelah pemberian materi dan tutorial sebagai post test yang memberikan umpan balik bagi tim pengabdian masyarakat.

Hasil dan Pembahasan

Setelah dilaksanakan kegiatan ini diharapkan guru sudah lebih familiar dan mampu menggunakan micorosotf office untuk kelancaran tugas sebagai guru. Tim pengabdian sebagai mitra memberikan solusi untuk melakukan terobosan kepada guru dengan mengikuti pelatihan beberapa cara pengerjaan dokumen, pengolahan data, dan presentasi dengan menggunakan program Microsoft. Ppeserta pelatihan lebih kepada tidak familiar dengan semua fungsi aplikasi di setiap program-program tersebut diatas, Diharapkan setelah kegiatan pelatihan ini diberikan akan memberikan dampak perubahan dan peningkatan pemahaman akan pentingnya memiliki ketrampilan tambahan untuk mendokumentasi dan mempresentasikan tugas-tugas yang dibebankan dari suatu program bagi guru dan staf.

Kegiatan pelatihan dilaksanakan pada tanggal 3 Agustus 2019 dengan menggunakan fasilitas ruang kelas SMP Al-Hamidiyah yang dihadiri Tim pengabdian masyarakat dan perkenalan dengan dosen-dosen yang akan memberi pelatihan. Peserta yang hadir sejumlah 11 orang peserta dari target peserta sebanyak 13 orang peserta. Ketidakhadiran ini disebabkan pada saat yang bersamaan terdapat kegiatan di sekolah lain. Materi yang diberikan pada pelatihan ini yaitu cara penggunaan program Microsoft word, excel, dan power point. Pelatihan ini cukup di respon dengan antusias oleh peserta karena contoh aplikasi yang diberikan adalah aktifitas dan kejadian yang dialami selama tugas sebagai guru. Dan hal ini dibuktikan dengan banyaknya pertanyaan yang disampaikan oleh peserta. 
Selanjutnya evaluasi dilakukan untuk mengukur target yang dijadwalkan. Tahapan evaluasi dilakukan untuk mengetahui tingkat pengetahuan dan pemahaman mengenai program komputer yang sederhana. Hal ini diberikan untuk melihat apakah peserta pelatihan bisa mengerjakan aplikasi lanjut, walau juga terkait ragam latar belakang sosial peserta. Evaluasi selanjutnya adalah melihat kemauan peserta pelatihan yang melebihi tingkat pengetahuan dan pemahaman dalam mengatasi kendala yang ada.

Dalam pelatihan microsoft word, setelah peserta diberikan pemahaman mengenai tujuan dan manfaatnya menggunakan perangkat lunak Microsoft Word, dilanjutkan pengoperasian dasar mulai dari membuat file baru, menyunting, menyimpan file dan mencopy file. Peserta mulai mempraktekkan secara langsung bagaimana mengetik di word dan lainnya. Peserta diberi kebebasan dalam membuat desain tulisan, susunan kalimat dalam bentuk formal atau informal. Ada pula peserta yang membuat soal-soal dan lainnya. Dengan pelatihan secara langsung manfaat pelatihan sudah dirasakan oleh peserta.

Sedangkan dalam pelatihan microsoft excel, banyak peserta yang mendapat keterampilan baru seperti cara membuat table, menghitung dengan mengunakan rumus untuk penjumlahan dan pengisian auto input, membuat rekap nilai, membuat urutan rangking kelas, dan lainnya.

Sedangkan microsoft power point baru sebatas membuat materi, memasukkan kalimat, gambar, tabel, dan lainnya.

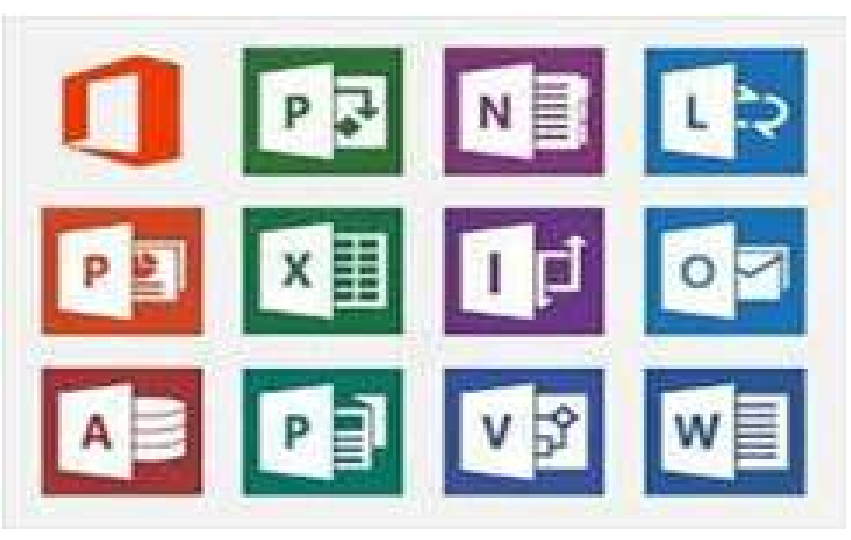

Gambar 1. Tampilan Icon Microsoft Office

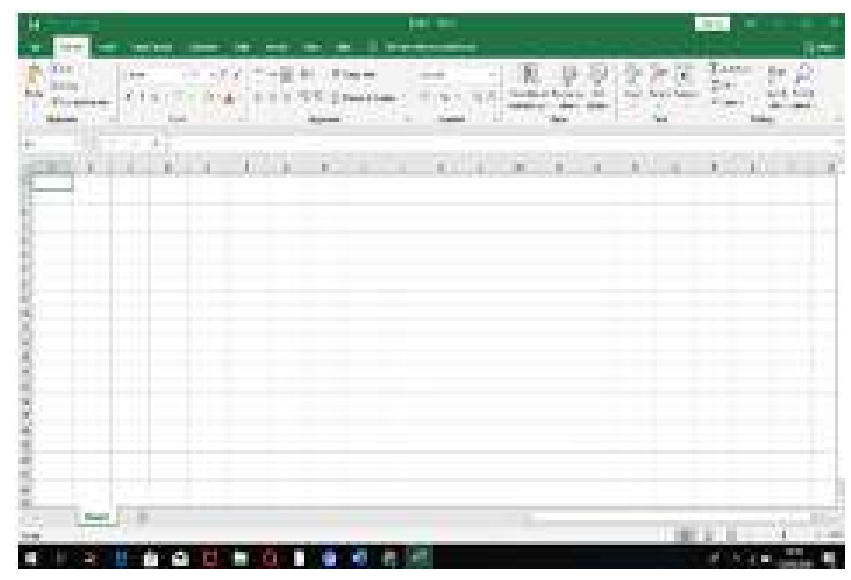

Gambar 3. Tampilan Icon Microsoft Excel

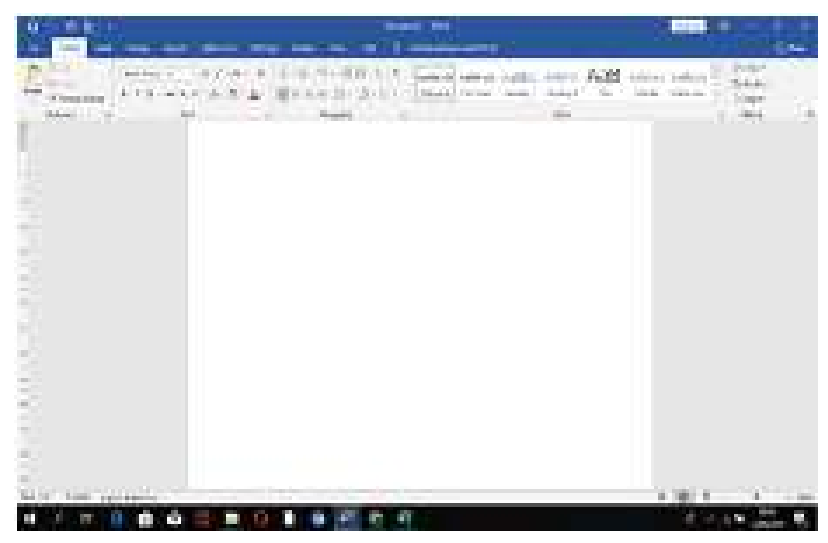

Gambar 2. Tampilan Microsoft Word

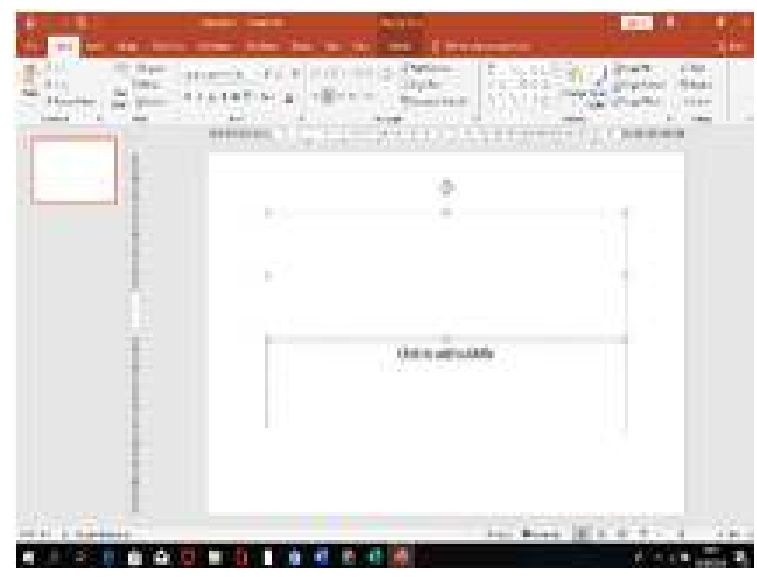

Gambar 4. Tampilan Microsoft Power point 
JAMALI-Volume. 01, Issue. 02, September 2019

Tabel 1. Rencana Kegiatan

\begin{tabular}{|c|c|c|}
\hline Rencana Kegiatan & Rincian Kegiatan & Target Luaran \\
\hline \multirow[t]{3}{*}{ Microsoft word } & Menganalisis aktifitas rutin peserta & \multirow{3}{*}{$\begin{array}{l}\text { Peserta mampu } \\
\text { menyelesaikan kesulitan }\end{array}$} \\
\hline & Membuat contoh aplikasi tugas rutin diatas & \\
\hline & $\begin{array}{l}\text { Mengidentifikasi kesulitan peserta pada } \\
\text { proses pelatihan }\end{array}$ & \\
\hline \multirow[t]{3}{*}{ Microsoft excel } & Menganalisis aktifitas rutin peserta & \multirow{3}{*}{$\begin{array}{l}\text { Peserta mampu mengatasi } \\
\text { kesulitan }\end{array}$} \\
\hline & Membuat contoh aplikasi tugas rutin diatas & \\
\hline & $\begin{array}{l}\text { Mengidentifikasi kesulitan peserta pada } \\
\text { proses pelatihan }\end{array}$ & \\
\hline \multirow{3}{*}{$\begin{array}{l}\text { Microsoft power } \\
\text { point }\end{array}$} & Menganalisis aktifitas rutin peserta & \multirow{3}{*}{$\begin{array}{l}\text { Peserta mampu mengatasi } \\
\text { kesulitan }\end{array}$} \\
\hline & Membuat contoh aplikasi tugas rutin diatas & \\
\hline & $\begin{array}{l}\text { Mengidentifikasi kesulitan peserta pada } \\
\text { proses pelatihan }\end{array}$ & \\
\hline \multirow[t]{3}{*}{ Pendampingan } & \multirow[t]{3}{*}{$\begin{array}{l}\text { Pendampingan dilakukan di ruang kelas } \\
\text { tempat dilaksanakannya pelatihan }\end{array}$} & $\begin{array}{l}\text { Mengetahui apakah materi } \\
\text { yang disampaikan difahami } \\
\text { atau tidak }\end{array}$ \\
\hline & & $\begin{array}{l}\text { Memberikan simulasi dan } \\
\text { bantuan teknis kepada peserta } \\
\text { yang mengalami kesulitan }\end{array}$ \\
\hline & & $\begin{array}{l}\text { Memberikan kepada setiap } \\
\text { peserta untuk menyelesaikan } \\
\text { materi secara tuntas }\end{array}$ \\
\hline
\end{tabular}



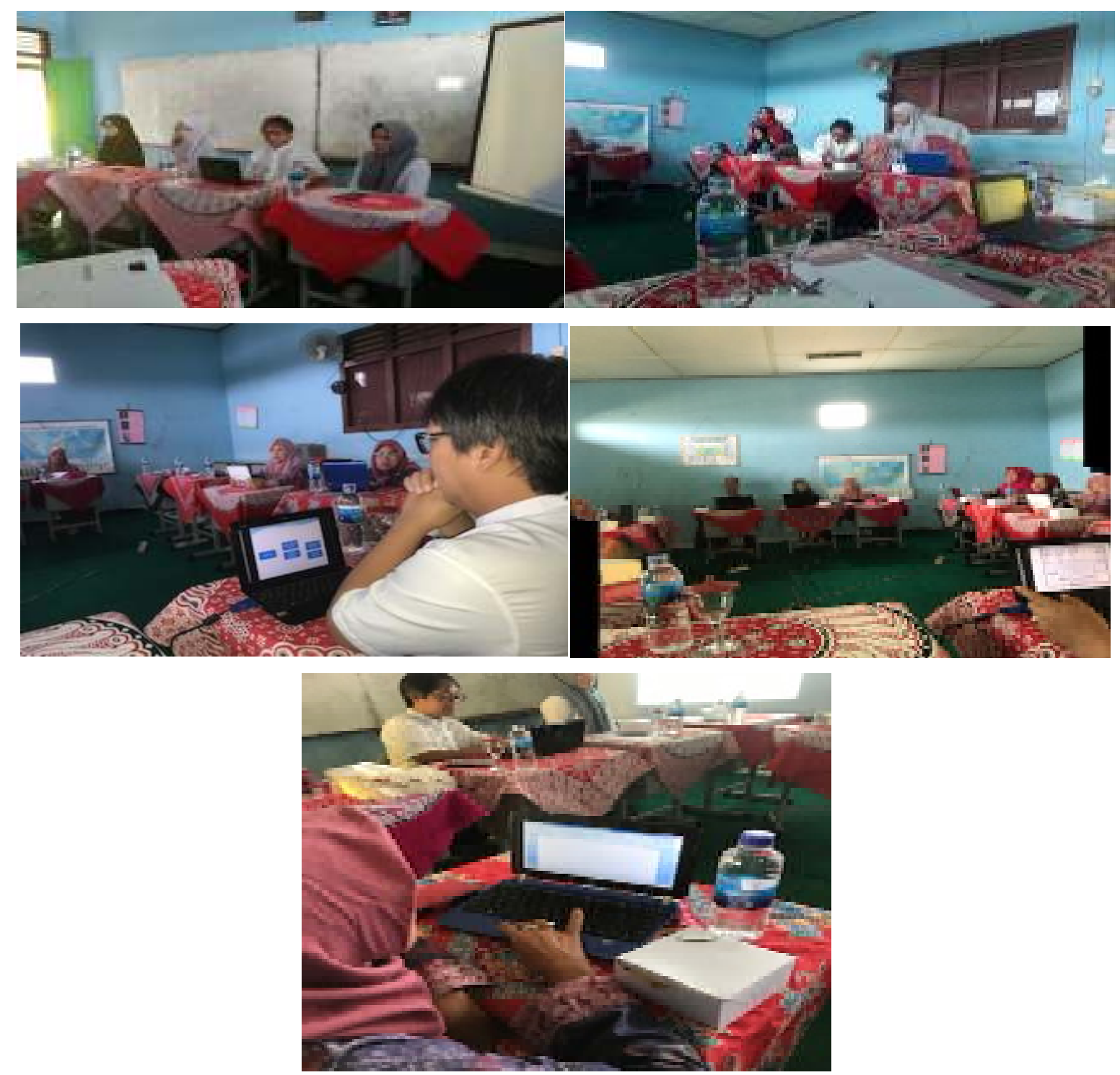

Gambar 5. Dokumentasi Kegiatan Pengabdian Kepada Masyarakat

\section{KESIMPULAN}

Kegiatan pengabdian kepada masyarakat dari Tim Pengabdian Universitas Muhammadiyah Palembang telah berjalan dengan cukup baik. Salah satu kendala yang dihadapi adalah adanya keterbatasan waktu yang singkat karena hanya dilakukan dalam 1 (satu) kali pertemuan dengan durasi 4 x 60 menit. Karena pelatihan ini bersifat praktek langsung, ke depan hendaknya ada pertemuan lanjutan untuk pemberian pelatihan yang lebih detil lagi.

\section{DAFTAR PUSTAKA}

Data Pokok SMP Al-Hamidiyah Palembang, SMP Al-HAMIDIYAH PALEMBANG. Sinkronisasi terakhir : 07 September 2019 pkl 14:21:36.040. [internet].[diunduh pada Sabtu 2019 September 14]. Tersedia pada http://dapo.dikdasmen.kemdikbud.go.id/sekolah/1CC13F866C322E9C5A90

Budiana, H. R., Sjafirah, N. A., \& Bakti, I. 2015. Pemanfaatan Informasi dan Komunikasi dalamPembelajaran. Dharmakarya: Jurnal Aplikasi Ipteks untuk Masyarakat , 4, 59-62. 
JAMALI - Volume. 01, Issue. 02, September 2019

Heny I. Pertiwi, 2018. Pelatihan Microsoft Office Untuk Karyawan dan Kelompok PKK Kelurahan Sawah Baru Tangerang Selatan, Sembadha, vol. 1, Edisi I.

Kajianpustaka. 2014. Pengertian Karaktiristik dan Manfaat Elearning. Retrieved Agustus 18, 2017 [internet]. [diunduh pada Sabtu 2019 September 14]. Tersedia pada http://www.kajianpustaka.com: www.kajianpustaka.com

Purwananti, Y. S., Meghantarai, B. A., \& Ciptaningtyas, A. D. 2015. Pembuatan Media Belajar Kreatif Berbasis Teknologi Informasi Bagi Mgmp Bahasa Inggris Smp I Tulungagung Sebagai Upaya Peningkatan Minat Belajar Anak Pada Mata Pelajaran Bahasa Inggris. J- ADIMAS (Jurnal Pengabdian kepada Masyarakat), 15-19.

Salamadian Desember 29, 2018. Pengertian Microsoft Word, Excel, Access, Power Point \& Fungsinya

Termasmedia. 2017. Pengertian Iternet.Retrieved Agustus 18, 2017 [internet]. [diunduh pada 2019 September 14]. Tersedia pada :http://www.termasmedia.com/lainnya/internet/71-pengertianinternet.ht

Undang-Undang Republik Indonesia. 2005. Undang-Undang Republik Indonesia Nomor 14 Tahun 2005 tentang Guru dan Dosen 